\title{
Alterations in the hematological parameters of rainbow trout (Oncorhynchus mykiss) injected with nonylphenol
}

\section{Nonilfenol enjekte edilen gökkuşağı alabalığı (Oncorhynchus mykiss) hematolojik parametrelerindeki değişimler}

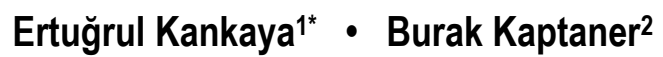 \\ 1 Faculty of Fisheries, Yuzuncu Yil University, 65080, Van-Turkey \\ 2 Department of Biology, Faculty of Science, Yuzuncu Yil University, 65080, Van-Turkey \\ * Corresponding author: ekankaya@yahoo.com
}

How to cite this paper:

Kankaya, E. \& Kaptaner, B. (2016). Nonilfenol enjekte edilen gökkuşağı alabalığı (Oncorhynchus mykiss) hematolojik parametrelerindeki değişimler. Ege Journal of Fisheries and Aquatic Sciences, 33(2): 139-142. doi: 10.12714/egejfas.2016.33.2.07

\begin{abstract}
This study was conducted to investigate the effect of nonylphenol (NP) on the hematological parameters of rainbow trout, Oncorhynchus mykiss, after 3 and 7 days of exposure. The fish were intraperitoneally injected with 5 and $50 \mathrm{mg} / \mathrm{kg}$ doses of NP. The red blood cell count decreased significantly with both doses of NP at 3 days post injection. The white blood cell values showed a significant increase at 3 days post injection with 50 mg/kg NP, and this increase was also observed with $5 \mathrm{mg} / \mathrm{kg} \mathrm{NP}$ at 7 days post injection. At 3 days post injection, hemoglobin was seen at significantly low levels, while the packed cell volume was at higher values with both doses of NP. No significant differences were observed in the erythrocyte sedimentation rate. The mean corpuscular volume showed significant increases at 3 days post injection, the mean corpuscular hemoglobin was observed to decrease with $5 \mathrm{mg} / \mathrm{kg} \mathrm{NP}$ at 7 days post injection, and the mean corpuscular hemoglobin concentration exhibited significantly lower values at 3 days post injection. In conclusion, this study indicated that the treatment concentrations of NP induced distinct hematological changes in rainbow trout.
\end{abstract}

Keywords: Nonylphenol, hematological parameters, rainbow trout

Öz: Bu çalışma, nonilfenole (NP) 3 ile 7 gün süreyle maruz bırakılan gökkuşağı alabalığı (Oncorhynchus mykiss)'nın kan parametreleri üzerindeki etkisini araştırmak için yürütülmüştür. NP balıklara 5 ve $50 \mathrm{mg} / \mathrm{kg}$ dozunda intraperitonal olarak enjekte edilmiştir. Enjeksiyondan 3 gün sonra NP'nin her iki dozunda eritrosit sayısı önemli olarak azalmıştır. Lökosit sayısı enjeksiyondan 3 gün sonra 50 mg/kg NP'de önemli olarak artış göstermiş ve bu artış enjeksiyondan 7 gün sonra 5 mg/kg NP'de de gözlenmiştir. Enjeksiyondan 3 gün sonra NP'nin her iki dozunda hematokrit yükselirken hemoglobin önemli olarak daha düşük seviyelerde görülmüştür. Eritrosit sedimantasyon oranında önemli bir fark gözlenmemiştir. Enjeksiyondan 3 gün sonra ortalama eritrosit hacminin önemli olarak artı̆̆ı görülmüştür. Eritrosit başına düşen ortalama hemoglobin miktarı enjeksiyondan 7 gün sonra $5 \mathrm{mg} / \mathrm{kg}$ NP'de azaldığı gözlenmiştir. Eritrosit başına düşen ortalama hemoglobin konsantrasyonunun enjeksiyondan 3 gün sonra önemli olarak düştüğü gösterilmiştir. Sonuçta bu çalışma, NP'nin uygulama dozlarının gökkuşağı alabalığında belirgin hematolojik değişiklikleri uyardığını göstermiştir.

Anahtar kelimeler: Nonilfenol, hematolojik parametreler, gökkuşağı alabalığı

\section{INTRODUCTION}

Alkylphenol polyethoxylates are extensively used chemicals in a wide variety of applications in industrial and agricultural areas. Nonylphenol (NP) ethoxylates, prominent among them, are utilized as surfactants in detergents, lubricants, antistatic agents, high-performance textiles, and scouring agents and emulsifiers for agrochemicals. When released into the environment, they are degraded into the more harmful compound, NP, by microorganisms (Vazquez-Duhalt et al. 2005). The occurrence of NP has been frequently detected in aquatic areas such as sediments, rivers, lagoons, and surface waters as a result of sewage discharge, and are reported to possess toxic and endocrine disrupting effects on fish (Kannan et al. 2003; Corsi and Focardi, 2002). NP accumulates in the tissues and causes organ toxicity in fish (Uguz et al. 2003; Shao et al. 2005). It has been demonstrated that NP primarily exhibits its adverse effects on the reproductive system in fish, and a variety of reproductive abnormalities including the feminization of males (Jobling et al. 1998), and altered steroid levels (Villeneuve et al. 2002) have been reported in the past. Due to its ability to bind to estrogen receptors, it induces the female-specific vitellogenin protein in male fish (Lech et al. 1996; Kinnberg et al. 2000; Li and Wang, 
2005). On the other hand, NP alters phase 1 and 2 biotransformation enzymes and weakens the capability of the detoxification mechanism in the liver of fish (Hughes and Gallagher, 2004; Vaccaro et al. 2005).

Hematological parameters have been widely preferred and used to assess the status of fish health with diseases or under stressful conditions (Blaxhall, 1972; Blaxhall and Daisley, 1973). Being fast and cheap, changes in these parameters have been also used in determining the toxicity of various environmental pollutants such as pesticides (Atamanalp et al. 2008; Svoboda et al. 2001) and heavy metals (Atamanalp et al. 2011; Mousavi and Yousefian, 2012) in different fish species. To date, hematological changes were reported in only a few limited studies on fish exposed to endocrine disrupting chemicals, i.e. in Korean rock fish (Sebastes schlegeli) injected with bisphenol A (Keum et al. 2005) and in juvenile common carp (Cyprinus carpio) exposed to NP and ethynylestradiol (Schwaiger et al. 2000). However, as far as we know, there are no available data effects of endocrine disrupting chemicals on the hematological parameters of rainbow trout (0. mykiss). Therefore, the present study aims to investigate the effect of NP on the hematological parameters of rainbow trout, a frequently consumed fish world-wide, and an important test organism recommended by the OECD guidelines (OECD, 1992).

\section{MATERIAL AND METHODS}

Rainbow trout (with an average weight of $156 \pm 29 \mathrm{~g}$ ) used in this study were obtained from a commercial fish farm and transferred to the Yuzuncu Yil University, Faculty of Fisheries, Practice and Research Facility in aerated containers. The fish were acclimated for 2 weeks in 300-L fiberglass circular tanks containing running dechlorinated tap water aerated by air pumps before the treatments. During this period, the fish were maintained under a natural photoperiod at an average temperature of $14.5^{\circ} \mathrm{C}$, fed commercial trout pellets, and the water in the tanks was cleaned daily to remove waste. All experimental procedures were carried out according to national animal care regulations.

After acclimation, NP (4-n-Nonylphenol; $\mathrm{C}_{5} \mathrm{H}_{24} \mathrm{O}$; (99.9\%); Riedel-de Haen) treatments were administered via a single intraperitoneal injection at doses of 5 and $50 \mathrm{mg} / \mathrm{kg}$. The dosage concentrations of NP were chosen according to the basis of the previous studies performed in the other fish species (Arukwe et al. 1997; Hughes and Gallagher, 2004; Vaccaro et al. 2005). The NP was dissolved in corn oil and the control groups consisted of 2 separate groups, non-injected and corn oil-injected fish. The experimental design consisted of 8 tanks with 7 fish in each one. During the treatments, the fish were fed commercial trout pellets, the water quality criteria in the tanks were monitored (temperature: $14.5^{\circ} \mathrm{C}$; $\mathrm{pH}$ : 8.38; dissolved oxygen: $5.66 \mathrm{mg} / \mathrm{L}$; conductivity: $846 \mu \mathrm{S} / \mathrm{cm}$; total hardness as CaCO3: $375 \mathrm{mg} / \mathrm{L}$; and total alkalinity as CaCO3: $565 \mathrm{mg} / \mathrm{L}$ ), and the tanks were cleaned daily. Before the injections, the fish were anaesthetized with Phenoxyethanol and weighted for the determination of the dosage per kilogram of body mass of each fish. At days 3 and 7 post vehicle-injection, the fish were anaesthetized and blood (approximately $2 \mathrm{cc}$ ) was taken from the caudal vein. The collected blood samples were placed in heparinized tubes and processed for hematological analyses.

The total red blood cell (RBC) and total white blood cell (WBC) counts were estimated according to the method of Blaxhall and Daisley (1973), the hemoglobin ( $\mathrm{Hb})$ concentration and erythrocyte sedimentation rate (ESR) were determined according to the method of Kocabatmaz and Ekingen (1984), and the packed cell volume (PCV) was determined according to the method of Schalm et al. (1975). The mean corpuscular volume (MCV), mean corpuscular hemoglobin (MCH), and mean corpuscular hemoglobin concentration $(\mathrm{MCHC})$ were calculated according to the method of Reddy and Bashamohideen (1989).

All of the data were analyzed using analysis of variance in the Statistical Package for the Social Sciences software, version 16.0. Duncan's multiple-range post hoc test was used for the determination of the statistical differences. The results were expressed as the mean \pm standard error of the mean (SEM) and the differences were considered statistically significant at $p<0.05$.

\section{RESULTS}

Hematological parameters of the treatment and control groups are presented in Table 1. According to the results, the RBC count decreased significantly with both doses of NP at 3 days post injection, and increased with $5 \mathrm{mg} / \mathrm{kg}$ but did not change with $50 \mathrm{mg} / \mathrm{kg}$ at 7 days post injection. The WBC values showed significant increases at 3 days post injection, and this increase was also observed with $5 \mathrm{mg} / \mathrm{kg}$ of NP at 7 days post injection; however, a marked decrease was observed in the WBC count with $50 \mathrm{mg} / \mathrm{kg}$ of NP at 7 days post injection. $\mathrm{Hb}$ was at significantly low levels at 3 days post injection. The PCV was at higher values with both doses of NP at 3 days post injection. No significant differences in the ESR were observed. The MCV showed significant increases at 3 days post injection but decreased with $5 \mathrm{mg} / \mathrm{kg}$ of NP at 7 days post injection. The $\mathrm{MCH}$ was observed to decrease with $5 \mathrm{mg} / \mathrm{kg}$ of NP at 7 days post injection. The MCHC exhibited significantly lower values at 3 days post injection. 
Table 1. Effects of different concentrations of NP on the hematological indices of rainbow trout after 3 and 7 days of exposure $(n=7)$

\begin{tabular}{|c|c|c|c|c|c|c|c|c|}
\hline \multirow[b]{2}{*}{ Parameters } & \multicolumn{4}{|c|}{ Day 3 post injection } & \multicolumn{4}{|c|}{ Day 7 post injection } \\
\hline & Control & Corn oil & $5 \mathrm{mg} / \mathrm{kg} \mathrm{NP}$ & $50 \mathrm{mg} / \mathrm{kg} \mathrm{NP}$ & Control & Corn oil & $5 \mathrm{mg} / \mathrm{kg} \mathrm{NP}$ & $50 \mathrm{mg} / \mathrm{kg} \mathrm{NP}$ \\
\hline $\begin{array}{l}\text { RBC } \\
\left(10^{6} / \mathrm{mm}^{3}\right)\end{array}$ & $1.15 \pm 0.06^{a b, 1}$ & $1.19 \pm 0.12^{\mathrm{ab}}$ & $1.07 \pm 0.11^{\mathrm{a}}$ & $1.01 \pm 0.06^{\mathrm{a}}$ & $1.22 \pm 0.06^{\mathrm{ab}}$ & $1.13 \pm 0.05^{\mathrm{ab}}$ & $1.36 \pm 0.11^{b}$ & $1.15 \pm 0.07 \mathrm{ab}$ \\
\hline $\begin{array}{l}\text { WBC } \\
\left(10^{4} / \mathrm{mm}^{3}\right)\end{array}$ & $3.17 \pm 0.18^{\mathrm{ab}}$ & $2.95 \pm 0.03^{\mathrm{ab}}$ & $4.05 \pm 0.48^{b}$ & $4.25 \pm 0.41^{b}$ & $3.30 \pm 0.23^{\mathrm{ab}}$ & $3.24 \pm 0.52^{\mathrm{ab}}$ & $3.53 \pm 0.67^{b}$ & $2.16 \pm 0.27^{a}$ \\
\hline $\begin{array}{l}\mathrm{Hb} \\
(\mathrm{g} / 100 \mathrm{~mL})\end{array}$ & $7.60 \pm 0.17^{a}$ & $7.65 \pm 0.19 \mathrm{a}$ & $6.7 \pm 0.10^{b}$ & $6.5 \pm 0.27^{\mathrm{b}}$ & $7.60 \pm 0.29 a$ & $7.63 \pm 0.09 \mathrm{a}$ & $7.63 \pm 0.18^{a}$ & $7.60 \pm 0.06^{a}$ \\
\hline $\begin{array}{l}\text { PCV } \\
(\%)\end{array}$ & $32.38 \pm 2.23^{a}$ & $33.32 \pm 2.70^{a}$ & $42.24 \pm 2.53^{\mathrm{ab}}$ & $35.33 \pm 3.35^{b}$ & $30.62 \pm 2.22^{a}$ & $27.38 \pm 1.46^{a}$ & $27.60 \pm 2.37 \mathrm{a}$ & $31.24 \pm 3.05^{\mathrm{a}}$ \\
\hline $\begin{array}{l}\text { ESR } \\
(\mathrm{mm} / \mathrm{h})\end{array}$ & $0.20 \pm 0.01^{a}$ & $0.24 \pm 0.02^{\mathrm{a}}$ & $0.20 \pm 0.02^{\mathrm{a}}$ & $0.24 \pm 0.02^{\mathrm{a}}$ & $0.19 \pm 0.05^{a}$ & $0.19 \pm 0.01^{\mathrm{a}}$ & $0.24 \pm 0.05^{\mathrm{a}}$ & $0.26 \pm 0.05^{a}$ \\
\hline $\begin{array}{l}\text { MCV } \\
\left(\mu m^{3}\right)\end{array}$ & $286.29 \pm 20.25^{a}$ & $290.02 \pm 22.15^{a}$ & $379.59 \pm 17.96^{b}$ & $369.81 \pm 53.43^{b}$ & $280.95 \pm 10.11^{\mathrm{a}}$ & $289.87 \pm 7.09 \mathrm{a}$ & $203.04 \pm 4.78 c$ & $299.14 \pm 12.20^{a}$ \\
\hline $\begin{array}{l}\mathrm{MCH} \\
(\mu \mathrm{g} / \mathrm{cell})\end{array}$ & $75.28 \pm 2.78^{a}$ & $72.40 \pm 4.59 \mathrm{a}$ & $75.35 \pm 11.75^{\mathrm{a}}$ & $73.53 \pm 3.23^{a}$ & $74.05 \pm 1.86^{a}$ & $72.03 \pm 4.84^{a}$ & $51.82 \pm 1.98^{b}$ & $74.24 \pm 1.97^{a}$ \\
\hline $\begin{array}{l}\mathrm{MCHC} \\
(\mathrm{g} / 100 \mathrm{~mL})\end{array}$ & $25.60 \pm 3.29 a$ & $25.90 \pm 1.05^{a}$ & $17.53 \pm 0.05^{b}$ & $21.30 \pm 2.77^{b}$ & $25.83 \pm 1.77^{\mathrm{a}}$ & $28.37 \pm 1.70 \mathrm{a}$ & $27.88 \pm 2.40 \mathrm{a}$ & $26.11 \pm 2.62 \mathrm{a}$ \\
\hline
\end{tabular}

\section{DISCUSSION}

$\mathrm{NP}$ treatments caused significant changes in the hematological parameters. The RBC count, $\mathrm{Hb}$, and $\mathrm{MCHC}$ were significantly decreased at 3 days post injection. The RBC count was increased at 7 days post injection with $5 \mathrm{mg} / \mathrm{kg}$ of NP. Similar findings were reported with a significant decrease in the RBC count, $\mathrm{Hb}$, and $\mathrm{MCHC}$ in juvenile $\mathrm{C}$. carpio after a 70-day exposure to NP and ethinylestradiol (EE2) (Schwaiger et al. 2000). Vazquez and Nostro (2014) observed a significant decrease in the RBC count and $\mathrm{Hb}$ in Cichlasoma dimerus after a 60-day exposure to $300 \mu \mathrm{g} / \mathrm{L}$ of 4-tert-octylphenol. Another study reported a significant decrease in the RBC count, $\mathrm{Hb}$, and $\mathrm{MCHC}$ in Clarias gariepinus after a 7-day exposure to 750 and $1000 \mu \mathrm{g} / \mathrm{L}$ of $\mathrm{NP}$ and octylphenol (OP), while there were increases in the RBC count and $\mathrm{Hb}$ with 250 and $500 \mu \mathrm{g} / \mathrm{L}$ of NP (Kumaran et al. 2011). Keum et al. (2005) also observed a decrease in the RBC count and $\mathrm{Hb}$ in S. schlegeli after a 15day exposure to bisphenol A. Similarly, the RBC counts were significant decreased in C. carpio after a 96-h exposure to diazinon (Svoboda et al. 2001), in Salmo trutta caspius exposed to mercuric chloride (Mousavi and Yousefian, 2012), in C. gariepinus after a 96-h exposure to cassava mill effluent (Adeyemo, 2005), and in C. gariepinus after a 14-day exposure via intramuscular injection with aqueous leaf extracts in Lepidagathis alopecuroides (Gabriel et al. 2009).

In the present study, the WBC counts were significantly increased in the other treatment groups, while decreases in the
WBC count were observed at 7 days post injection with 50 $\mathrm{mg} / \mathrm{kg}$ of NP. Schwaiger et al. (2000) also observed a decrease in the total number of circulating leukocytes in carp after prolonged exposure to 5 and $15 \mu \mathrm{g} / \mathrm{L}$ of NP and EE2-treated fish. Likewise, this parameter was observed to increase in treatment groups with NP and OP (Kumaran et al. 2011). The MCV was significantly increased at 3 days post injection with both NP doses, but was then seen to decrease at 7 days post injection with $5 \mathrm{mg} / \mathrm{kg}$ of NP. The same significant increase in the MCV was reported with 500,750 , and $1000 \mu \mathrm{g} / \mathrm{L}$ of NP, while decreases were observed with $250 \mu \mathrm{g} / \mathrm{L}$ of NP (Kumaran et al. 2011). In the same study, significant increases were observed in the MCV with 250,500 , and $750 \mu \mathrm{g} / \mathrm{L}$ of NP, while decreases were observed with $1000 \mu \mathrm{g} / \mathrm{L}$ of OP. Schwaiger et al. (2000) reported a significant increase in the MCV in carp after prolonged exposure to $15 \mu \mathrm{g} / \mathrm{L}$ of NP.

A significant increase in the PCV was observed at 3 days post injection. In a study of $C$. gariepinus exposed to NP and OP, Kumaran et al. (2011) observed a significant increase in the hematocrit values with doses of 250 and $500 \mu \mathrm{g} / \mathrm{L}$, and decreases with doses of 750 and $1000 \mu \mathrm{g} / \mathrm{L}$. In another study, $\mathrm{NP}$ and EE2 caused to no significant changes in the PCV value of juvenile $C$. carpio.

In the present study, no significant differences in the ESR were observed between the treatment and control groups, whereas in the $\mathrm{MCH}$ showed a significant decrease at 7 days post injection with $5 \mathrm{mg} / \mathrm{kg}$ of NP. Likewise, Kumaran et al. 
(2011) also reported that the $\mathrm{MCH}$ decreased with $250 \mu \mathrm{g} / \mathrm{L}$ of $\mathrm{NP}$, and 750 and $1000 \mu \mathrm{g} / \mathrm{L}$ of OP. This study indicated that the treatment concentrations of NP induced hematological changes in rainbow trout.

\section{REFERENCES}

Adeyemo, O.K. (2005). Haematological and histopathological effects of Cassava mill effluent in Clarias gariepinus. African Journal Biomedical Research, 8(3): 179-183. doi:10.4314/ajbr.v8i3.35747

Arukwe, A., Förlin, L., \& Goksoyr, A. (1997). Xenobiotic and steroid biotransformation enzymes in atlantic salmon (Salmo salar) liver treated with an estrogenic compound, 4-nonylphenol. Environmental Toxicology and Chemistry, 16(12): 2576-2583. doi:10.1002/etc.5620161220

Atamanalp, M., Aksakal, E., Kocaman, E.M., Uçar, A., Şişman, T., \& Türkez, H. (2011). The alterations in the hematological parameters of rainbow trout, Oncorhynchus mykiss, exposed to cobalt chloride. Journal of the Faculty of Veterinary Medicine, Kafkas University, 17: 73-76. doi:10.9775/kvfd.2010.3393

Atamanalp, M., Angis, S., Oguzhan, P., \& Aksakal, E. (2008). Alterations in hematological parameters of rainbow trout (Oncorhynchus mykiss) exposed to DDVP. The Israeli Journal of Aquaculture-Bamidgeh, 60(1): 912.

Blaxhall, P.C., \& Daisley, K.W. (1973). Routine Haematological Methods for use Fish with Blood. Journal of Fish Biology, 5(6): 771-781. doi:10.1111/j.1095-8649.1973.tb04510.x

Blaxhall, P.C. (1972). The Haematological Assessment of the Health of Freshwater Fish. A Rewiev of Selected Literature. Journal of Fish Biology, 4(4): 593-604. doi:10.1111/j.1095-8649.1972.tb05704.x

Corsi, I., \& Focardi, S. (2002). Nonylphenols in a lagoon environment: pnonylphenol and nonylphenol ethoxylates in fish tissue. Bulletin of Environmental Contamination and Toxicology, 68(6): 908-914. doi:10.1007/s00128-002-0040-7

Gabriel, U.U., Obomanu, F.G., \& Edori, O.S. (2009). Haematology, plasma enzymes and organ indices of Clarias gariepinus after intramuscular injection with aqueous leaves extracts of Lepidagathis alopecuroides. African Journal of Biochemistry Research, 3(9): 312-316.

Hughes, E.M., \& Gallagher, E.P. (2004). Effects of 17- $\beta$ estradiol and 4nonylphenol on phase II electrophilic detoxification pathways in largemouth bass (Micropterus salmoides) liver. Comparative Biochemistry and Physiology Part C: Toxicology and Pharmacology, 137(3): 237-247. doi:10.1016/j.cca.2004.01.006

Jobling, S., Nolan, M., Tyler, C.R., Brighty, G., \& Sumpter, J.P. (1998) Widespread sexual disruption in wild fish. Environmental Science and Technology, 32(17): 2498-2506. doi:10.1021/es9710870

Kannan, K., Keith, T.L., Nalor, C.G., Staples, A., Synder, S.A., \& Giesy, J.P. (2003). Nonylphenol and nonylphenol ethoxylates in fish, sediment, and water from the Kalamazoo River, Michigan. Archives of Environmental Contamination and Toxicology, 44(1): 77-82. doi:10.1007/s00244-002-1267-3

Keum, Y.H., Jee, J.H., Lee, O.H., Park, S.I., \& Kang, J.C. (2005). In vivo effects of bisphenol A exposure on haematological parameters in Korean rockfish, Sebastes schlegeli. Journal of Fish Pathology, 18(3): 293-300.

Kinnberg, K., Korsgaard, B., Bjerregaard, P., \& Jespersen, A. (2000). Effects of nonylphenol and $17 \beta$-estradiol on vitellogenin synthesis and testis morphology in male platyfish Xiphophorus maculates. The Journal of Experimental Biology, 203(2): 171-181.

Kocabatmaz, M., \& Ekingen, G. (1984). Taking blood sample in different fish species and standardization of hematological methods. Doğa Bilim Dergisi, 8(2): 149-159.

Kumaran, S.S., Kavitha, C., Ramesh, M., \& Grummt, T. (2011). Toxicity studies of nonylphenol and octylphenol: hormonal, hematological and biochemical

\section{ACKNOWLEDGEMENT}

The authors are thankful to the Şifa Trout Farm authorities for providing the fish.

effects in Clarias gariepinus. Journal of Applied Toxicology, 31(8): 752761. doi:10.1002/jat.1629

Lech, J.J., Lewis, S.K., \& Ren, L. (1996). In vivo estrogenic activity of nonylphenol in rainbow trout. Fundamental and Applied Toxicology, 30(2): 229-232. doi:10.1093/toxsci/30.2.229

Li, M.H., \& Wang, Z.R. (2005). Effect of nonylphenol on plasma vitellogenin of male adult guppies (Poecilia reticulata). Environmental Toxicology, 20(1): 53-59. doi:10.1002/tox.20077

Mousavi, S.E., \& Yousefian, M. (2012). The alterations in the hematological parameters of endangered Caspian brown trout, Salmo trutta caspius, exposed to waterborne mercuric chloride. Asian Journal of Animal Sciences, 6(4): 154-163. doi:10.3923/ajas.2012.154.163

OECD. (1992). OECD guideline for testing of chemicals. Fish, acute toxicity test. The Organisation for Economic Co-operation and Development (OECD), 203: 1-9. doi:10.1787/9789264069961-en

Reddy, P.M., \& Bashamoideen, M.D. (1989). Fenvalarate and Cypermethrin Induced Changes in the Haematological Parameters of Cyprinus carpio. Acta Hydrochimica et Hydrobiologica, 17(1): 101-107. doi:10.1002/aheh.19890170116

Schalm, O.W., Jain, N.C., \& Carrol, E.J. (1975). Veterinary Haematology. 3rd edn. Lea and Febiger (US).

Schwaiger, J., Spieser, O.H., Bauer, C., Ferling, H., Mallow, U., Kalbfus, W., \& Negele, R.D. (2000). Chronic toxicity of nonylphenol and ethinylestradiol: haematological and histopathological effects in juvenile common carp (Cyprinus carpio). Aquatic Toxicology, 51(1): 69-78. doi:10.1016/S0166-445X(00)00098-9

Shao, B., Hu, J., Yang, M., An, W., \& Tao, S. (2005). Nonylphenol and nonylphenol ethoxylates in river, drinking water, and fish tissues in the area of Chongqing, China. Archives of Environmental Contamination and Toxicology, 48(4): 467-473. doi:10.1007/s00244-003-0266-3

Svoboda, M., Luskova, V., Drastichova, J., \& Zlabek, V. (2001). The effect of diazinon on haematological indices of common carp (Cyprinus carpio L.). Acta Veterinaria Brno., 70: 457-465. doi:10.2754/avb200170040457

Uguz, C., Iscan, M., Ergüven, A., Isgor, B., \& Togan, I. (2003). The bioaccumulation of nonylphenol and its adverse effect on the liver of rainbow trout (Onchorynchus mykiss). Environmental Research, 92(3): 262-270. doi:10.1016/S0013-9351(03)00033-1

Vaccaro, E., Meucci, V., Intorre, L., Soldani, G., Di Bello, D., Longo, V., Gervasi, P.G., \& Pretti, C. (2005). Effects of $17 \beta$-estradiol, 4-nonylphenol and PCB 126 on the estrogenic activity and phase 1 and 2 biotransformation enzymes in male sea bass (Dicentrarchus labrax). Aquatic Toxicology, 75(4): 293-305. doi:10.1016/j.aquatox.2005.08.009

Vazquez, G.R., \& Nostro, F.L. (2014). Changes in hematological parameters of Cichlasoma dimerus (Teleostei, Perciformes) exposed to sublethal concentrations of 4-tert-octylphenol. Archives of Environmental Contamination and Toxicology, 66(3): 463-469. doi:10.1007/s00244-014-9997-6

Vazquez-Duhalt, R., Marquez-Rocha, F., Ponce, E., Licea, A.F., \& Viana, M.T. (2005). Nonylphenol, an integrated vision of a pollutant. Scientific review. Applied Ecology and Environmental Research, 4(1): 1-25. doi:10.15666/aeer/0401_001025

Villeneuve, D.L., Villalobos, S.A., Keith, T.L., Snyder, E.M., Fitzgerald, S.D., \& Giesy, J.P. (2002). Effects of waterborne exposure to 4-nonylphenol on plasma sex steroid and vitellogenin concentrations in sexually mature male carp (Cyprinus carpio). Chemosphere, 47(1):15-28. doi:10.1016/S0045-6535(01)00212-0 